\title{
A pre-S gene chip to detect pre-S deletions in hepatitis B virus large surface antigen as a predictive marker for hepatoma risk in chronic hepatitis $B$ virus carriers
}

\author{
Fan-Ching Shen ${ }^{1}$, Ih-Jen Su${ }^{4}$, Han-Chieh Wu${ }^{4}$, Yi-Hsuan Hsieh², Wei- \\ Jen $\mathrm{Yao}^{6}$, Kung-Chia Young ${ }^{1}$, Tsung-Chuan Chang1, Hui-Chuan Hsieh ${ }^{2}$, Han- \\ $\mathrm{Ni} \mathrm{Tsai}^{2}$ and Wenya Huang*1,2,5,3
}

\begin{abstract}
Address: ${ }^{1}$ Department of Medical Laboratory Science and Biotechnology, National Cheng Kung University, Tainan, Taiwan, Republic of China, ${ }^{2}$ Institute of Basic Medicine, National Cheng Kung University, Tainan, Taiwan, Republic of China, ${ }^{3}$ Center for Signal Transduction and Gene Regulation, National Cheng Kung University, Tainan, Taiwan, Republic of China, ${ }^{4}$ Division of Infectious Diseases, National Health Research Institutes, Tainan, Taiwan, Republic of China, ${ }^{5}$ Laboratory of Molecular Diagnostics, Department of Pathology, National Cheng Kung University Hospital, Tainan, Taiwan, Republic of China and ' ${ }^{\circ}$ Department of Radiology, National Cheng Kung University Hospital, Tainan, Taiwan, Republic of China

Email: Fan-Ching Shen - jin2348257@hotmail.com; Ih-Jen Su - suihjen@nhri.org.tw; Han-Chieh Wu - hanjie@nhri.org.tw; Yi-

Hsuan Hsieh - rnapolymerase@hotmail.com; Wei-Jen Yao - wjyao@mail.ncku.edu.tw; Kung-Chia Young - t7908077@mail.ncku.edu.tw; TsungChuan Chang - tsungcha@mail.ncku.edu.tw; Hui-Chuan Hsieh - chou827@hotmail.com; Han-Ni Tsai - pin36.tw@yahoo.com.tw;

Wenya Huang* - whuang@mail.ncku.edu.tw

* Corresponding author
\end{abstract}

Published: I5 September 2009

Journal of Biomedical Science 2009, 16:84 doi:10.1 186/1423-0127-16-84

This article is available from: http://www.jbiomedsci.com/content//6/I/84

(c) 2009 Shen et al; licensee BioMed Central Ltd.

This is an Open Access article distributed under the terms of the Creative Commons Attribution License (http://creativecommons.org/licenses/by/2.0), which permits unrestricted use, distribution, and reproduction in any medium, provided the original work is properly cited.
Received: 13 June 2009

Accepted: 15 September 2009

\begin{abstract}
Background: Chronic hepatitis B virus (HBV) infection is an important cause of hepatocellular carcinoma (HCC) worldwide. The pre- $\mathrm{S}_{1}$ and $-\mathrm{S}_{2}$ mutant large HBV surface antigen (LHBS), in which the pre- $S_{1}$ and $-S_{2}$ regions of the LHBS gene are partially deleted, are highly associated with HBV-related HCC.
\end{abstract}

Methods: The pre-S region of the LHBS gene in two hundred and one HBV-positive serum samples was PCR-amplified and sequenced. A pre-S oligonucleotide gene chip was developed to efficiently detect pre-S deletions in chronic HBV carriers. Twenty serum samples from chronic HBV carriers were analyzed using the chip.

Results: The pre-S deletion rates were relatively low (7\%) in the sera of patients with acute HBV infection. They gradually increased in periods of persistent HBV infection: pre-S mutation rates were $37 \%$ in chronic HBV carriers, and as high as $60 \%$ in HCC patients. The Pre-S Gene Chip offers a highly sensitive and specific method for pre-S deletion detection and is less expensive and more efficient (turnaround time 3 days) than DNA sequencing analysis.

Conclusion: The pre- $S_{I / 2}$ mutants may emerge during the long-term persistence of the HBV genome in carriers and facilitate HCC development. Combined detection of pre-S mutations, other markers of HBV replication, and viral titers, offers a reliable predictive method for HCC risks in chronic HBV carriers. 


\section{Background}

Chronic hepatitis B virus infection is a major cause of HCC worldwide and its most important cause in Asia [16]. HBV infection occurs primarily through blood or body fluid transmission. HBV-related HCC often occurs at the age of 40 or older, suggesting that HBV may persist in carriers for decades before HCC actually develops [6,7]. Long-term monitoring of chronic HBV carriers is important to help prevent HCC. Furthermore, implementing cancer therapies at early disease stages is beneficial. The HBV markers commonly used to monitor the viral status in chronic HBV carriers are viral DNA titers, HBV surface and core antigens, and hepatitis B envelope (HBe) antigen $[7,8]$. Combined detection of these markers reveals the status of virus replication as well as the number of virus particles in host hepatocytes. Active HBV viral replication and high virus titers are associated with the severity of HBV-induced liver inflammation, fibrosis, cirrhosis, and HCC $[9,10]$.

In the late 1990s, two major types of pre-S deletion mutant LHBS were identified and highly associated with HCC $[11,12]$. LHBS is expressed primarily at the late stage of chronic HBV infection, after the viral genome has integrated into the host chromosome [13-16]. Pre-S mutant LHBS was first isolated from ground-glass hepatocytes (GGH), the histological hallmarks of the late stages of chronic HBV infection, and is often seen in the liver sections of HCC patients [17]. Pre-S mutant LHBS is highly associated with advanced liver diseases, including cirrhosis and HCC, which suggests that it contributes to hepatocellular carcinogenesis [18-26]. In the two types of pre-S mutant LHBS, pre- $S_{1}$ and pre- $S_{2}$ mutant LHBS, the pre- $S_{1}$ and $-S_{2}$ regions are, respectively, partially deleted (Fig. 1) $[11,12]$. They accumulate in endoplasmic reticulum (ER) and induce strong ER stress [27]. Through an ER stressmediated pathway, they cause oxidative stress and DNA damage [28]. Through an ER stress-independent pathway, however, pre- $\mathrm{S}_{2}$ mutant LHBS contributes to the increased proliferation of hepatocytes [29]. Pre- $S_{2}$ mutant LHBS also interacts with c-Jun activation domain-binding protein 1 (JAB1) and induces p27 ${ }^{\mathrm{Kip} 1}$ degradation and cell-cycle progression [30]. Through an unknown mechanism, pre$\mathrm{S}_{2}$ mutant LHBS also induces significant cyclin A expression [29]. Based on the findings of these previous studies, pre-S mutant LHBS, especially the pre- $\mathrm{S}_{2}$ type, is believed to be crucial in HBV-associated hepatocellular carcinogenesis.

After pre-S mutant LHBS was discovered, various geographically diverse studies [18-26] screening for pre-S mutations invariably reported that they were prevalent in chronic HBV carriers. In addition, pre-S mutant LHBS, especially the pre- $S_{2}$ type, is highly correlated with the severity of HBV-related liver diseases, including HCC [20-

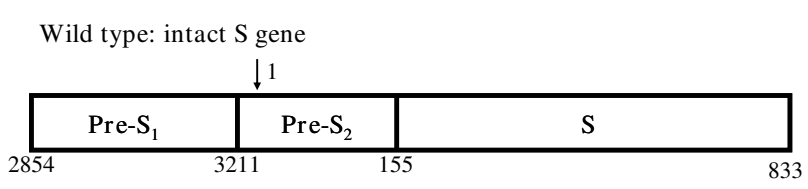

Pre-S $S_{1}$ deletion mutant

\begin{tabular}{|l|l|l|ll|}
\hline & Pre-S & & Pre-S & S \\
\hline
\end{tabular}

Pre- $\mathrm{S}_{2}$ deletion mutant

\begin{tabular}{|l|l|l|ll|}
\hline Pre-S & Pre-S $_{1}$ & S \\
\hline
\end{tabular}

Figure I

Representatives of the wild-type, pre- $S_{1}$, and pre- $S_{2}$ mutant LHBS gene. The shaded boxes are the regions deleted in the pre- $S_{1}$ and pre- $S_{2}$ mutant LHBS. The numbers on the bottom of the gene indicate the pre- $S_{1}, S_{2}$, and $S$ regions of the LHBS gene in nucleotide order. Nucleotide $I$ is the start of the circular genome and the numbers go clockwise. The last nt number is 3221 . Here only the $S$ gene, which spans the start of the genome, is shown. The arrow at the top of the diagram indicates the start (nt I) of the HBV genome.

$23,25]$. Therefore, it is important to screen for pre-S deletion mutations in chronic HBV carriers. This type of screening should be done in combination with the detection of other HBV markers, such as viral titers and HBe antigen (Ag), to estimate an HBV carrier's relative risk for HCC.

Identifying pre-S mutations in chronic HBV carriers usually requires multiple experimental procedures, because most pre-S mutants co-exist with wild-type LHBS in blood and hepatocytes; this is probably due to the emergence of the pre-S mutant from the wild-type form. One individual carrier often simultaneously presents multiple pre-S mutant forms that need to be singly cloned and then sequenced. This is both time-consuming and expensive, which makes it difficult to screen large populations of chronic HBV carriers. We developed a convenient and cost-effective oligonucleotide array system for screening pre-S deletions in the LHBS gene. Using this system, we omitted traditional DNA sequencing and shortened the detection procedure from about 7 days to no longer than 3 working days.

\section{Materials and methods \\ Reagents and participants}

The pre-S region of the LHBS gene in two hundred and one HBV-positive serum samples, collected at the National Cheng Kung University Hospital from 2000 
through 2002, was PCR-amplified and sequenced [31]. To develop the Pre-S Gene Chip system, 20 HBV-DNA-positive serum samples were obtained from Kung-Chia Young, PhD, at National Cheng Kung University. The pre$S$ region of the LHBS gene was PCR-amplified and sequenced [31]. The DNA sequences were used to design oligonucleotide probes on the Pre-S Gene Chip. To test the efficacy of the chip, another 20 serum samples from chronic HBV carriers were obtained from the Center for Disease Control, Taipei, Taiwan, and analyzed using the chip. A DNA extraction kit (QIAamp MinElute Virus Spin kit; Qiagen Inc., Valencia, CA) was used to extract the virus DNA in serum. Most of the common chemicals used for chip hybridization were purchased from Sigma-Aldrich Co., St Louis, MO.

\section{The Pre-S Gene Chip}

The oligonucleotide DNA probe $(20 \mu \mathrm{M})$ was prepared in DNA tracking dye ( $5 \mathrm{mM}$ Tris- $\mathrm{HCl}, 0.5 \mathrm{mM} \mathrm{Na}_{2}$ EDTA, $0.75 \mathrm{mg} / \mathrm{mL}$ bromophenol blue, $15 \%$ glycerol [pH 7.5]). The 42 DNA probes spanning the pre-S region (532 nucleotides (nt)) of the LHBS gene were spotted on positivelycharged nylon membrane, using an arrayer (Ezspot Robotic Arrayer; EZlife Technology, Inc., Taipei, Taiwan) with a solid pin $400 \mu \mathrm{m}$ in diameter. The probes ranged from 25 to $30 \mathrm{nt}$ long, and some were linked with 15 to 17 thymidines at the $5^{\prime}$ ends. Redundant probes were designed to target the genetically polymorphic regions in the gene (Fig. 2). After the probes had been spotted, the DNA on the membrane was ultravioletly (UV) crosslinked (Stratalinker UV Crosslinker; Stratagene, La Jolla, $\mathrm{CA})$ to the nylon membrane.

\section{Polymerase chain reaction}

The pre-S LHBS gene was PCR amplified by using the primers $1 \mathrm{~F}$ (digoxigenin labeled at the $5^{\prime}$ end) and $1 \mathrm{R}$ (Table 1). In cases where no visible DNA products were seen using agarose gel electrophoresis because of low viral titers in the serum samples, nested PCR using the primers $1 \mathrm{~F}$ and $2 \mathrm{R}$ was then done (Fig. 3). For E. coli colony PCR, the M13 Forward (digoxigenin labeled at the 5 ' end) and M13 Reverse primers (Invitrogen, Inc., Carlsbad, CA) were used. The PCR mix contained 10 ng of template DNA, 0.2 $\mu \mathrm{M}$ of each primer, $200 \mu \mathrm{M}$ of each dNTP, 0.5 units of SuperTherm Fold DNA polymerase (JMR Holdings, Inc., Commerce Township, MI) with $1.5 \mathrm{mM}$ of $\mathrm{MgCl}_{2}, 25 \mathrm{mM}$ of $\mathrm{N}$ - [Tris (hydroxymethyl) methyl]-3-aminopropanesulfonic acid (TAPS [pH 9.3]), $50 \mathrm{mM}$ of $\mathrm{KCl}, 2 \mathrm{mM}$ of $\mathrm{MgCl}_{2}, 1 \mathrm{mM}$ of $\beta$-mercaptoethanol, and $0.25 \mu \mathrm{g} / \mu \mathrm{L}$ of

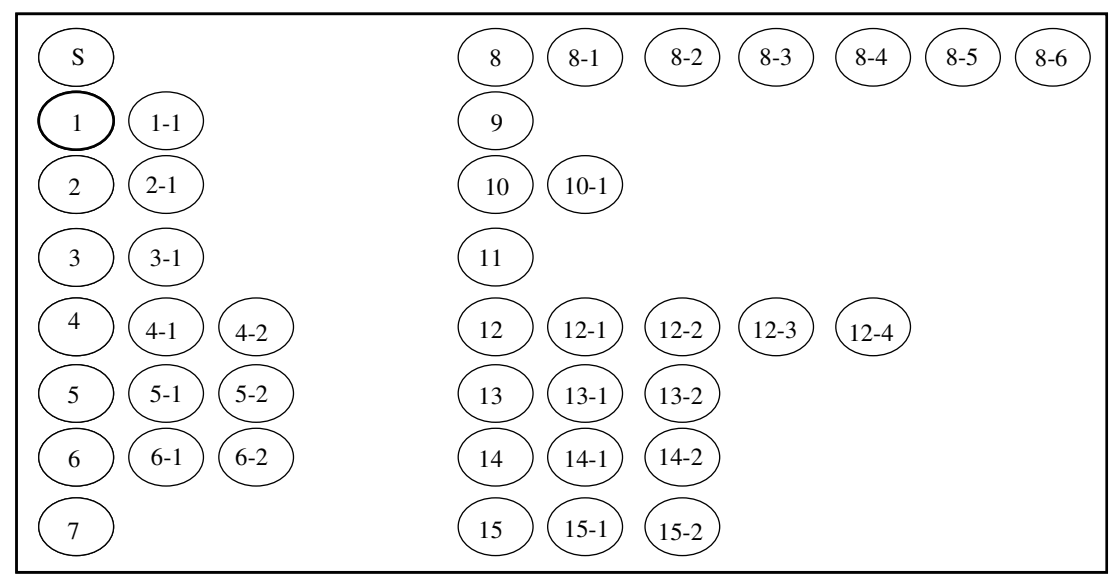

S (start): nt. 2854 2878

P1 \& 1-1: nt. 2894 2923

P2 \& 2-1: nt. 2924 2953

P3 \& 3-1: nt. 2954 2983

P4, 4-1 \& 4-2: nt. 2984 3013

P5, 5-1 \& 5-2: nt. 3014 3043

P6 \& 6-2: nt. 3044 3073
P6-1: nt. 3045 3071

P7: nt. 3074 3103

P8, 8-1 \& 8-4: nt. 3104 3133

P8-2 \& 8-5: nt. 3088 3117

P8-3 \& 8-6: nt. 3118 3147

P9: nt. 3134 3163

P10 \& 10-1: nt. 3164 3193
P11: nt. 3194 2

P12 \& 12-2: nt. 3 32

P12-1, 12-3 \& 12-4: nt. 5 31

P13 \& 13-2: nt. 33 62

P13-1: nt. 35 61

P14, 14-1 \& 14-2: nt. 63 92

P15, 15-1 \& 15-2: nt. 93 122

\section{Figure 2}

The Pre-S Gene Chip. The chip $(7 \mathrm{~mm}(\mathrm{H}) \times 10 \mathrm{~mm}(\mathrm{~W}))$ contains 42 oligonucleotide probes spanning the pre-S regions. The target region of each probe is indicated in the order of the nucleotides below the chip. The probes with extension numbers (e.g., 8-I, 8-2,... 8-6) are the redundant probes that target the same regions as the primary probes (e.g., 8) do. 
Table I: The PCR primers used in this study.

\begin{tabular}{lll}
\hline Primer & Sequence & Comment \\
\hline Primer-IF & 5'-GCGGGTCACCATATTCTTGGG-3' & HBV genome nt 28I8 to nt 2837 \\
\hline Primer-IR & 5'-GAGTCTAGACTCTGCGGTAT-3' & HBV genome nt 236 to nt 255 \\
\hline Primer-2R & 5'-TAACACGAGCAGGGGTCCTA-3' & HBV genome nt I80 to nt I99 \\
\hline MI3 Forward primer & 5'-GTAAAACGACGGCCAGT-3' & \\
\hline MI3 Reverse primer & 5'-AACAGCTATGACCATG-3' & \\
\hline
\end{tabular}

nt, nucleotide

activated calf thymus DNA. Agarose gel electrophoresis was used to examined the PCR products.

\section{TA cloning}

In cases where multiple pre-S PCR products were revealed, E. coli TA cloning was done. Three microliters of PCR product was ligated with $50 \mathrm{ng}$ of TA cloning vector (pCR

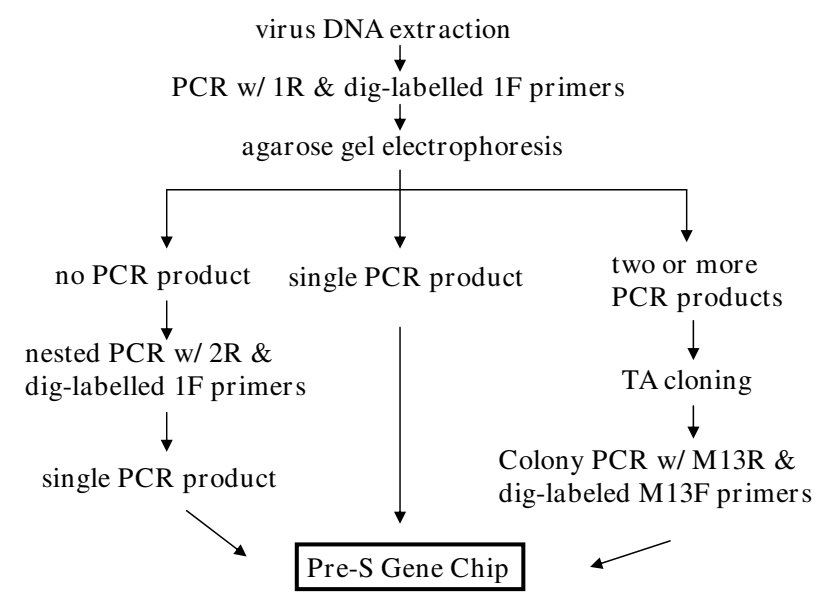

Figure 3

Working scheme of Pre-S Gene Chip analysis. The virus DNA is extracted from the patient's blood or liver tissue. The pre-S region is PCR-amplified using PCR-IR and 5'dig-labeled IF primers. The PCR products are visualized using agarose gel electrophoresis and ethidium bromide staining. In cases where no PCR products are seen---perhaps because of a low HBV DNA titer---nested PCR using PCR-2R and 5'-diglabeled IF primers is done. When only a single PCR product is seen, the DNA product is directly subjected to chip hybridization. However, when two or more different types of pre-S PCR products are seen in agarose gel, the products are first directed to TA cloning. Multiple plasmid clones are then analyzed using colony PCR with MI3R and 5'-dig-labeled I3F primers. These PCR products are then analyzed using the Pre-S Gene Chip.
2.1; Invitrogen) at $14{ }^{\circ} \mathrm{C}$ overnight. The next day, the ligation product was transformed into an E. coli DH5 $\alpha$ strain. The pre-S insert-DNA was then examined using colony PCR. For the DNA sequencing analysis, the colony PCR products were purified using a kit (PCR Clean-Up Kit; Roche Applied Sciences, Indianapolis, IN) and sent to our university's DNA Sequencing Facility for analysis.

\section{Pre-S Gene Chip analysis}

The pre-S chip was placed in a 24-well culture plate, soaked in $0.2 \times$ standard sodium citrate (SSC: $150 \mathrm{mM}$ $\mathrm{NaCl}, 15 \mathrm{mM} \mathrm{NaH}{ }_{2}\left(\mathrm{C}_{3} \mathrm{H}_{5} \mathrm{O}(\mathrm{COO})_{3}[\mathrm{pH} 7.0]\right)$, and then rinsed twice with the same solution. For pre-hybridization, the chip was then gently shaken in microarray hybridization buffer $(5 \times$ SSC, $1 \%$ blocking reagent (Roche), $0.1 \%$ N-lauroylsarcosine, $0.02 \%$ SDS) at room temperature for $2 \mathrm{~h}$. The chip was then hybridized with 10 $\mu \mathrm{L}$ of heat-denatured PCR product in $300 \mu \mathrm{L}$ of hybridization buffer at $50^{\circ} \mathrm{C}$ for 90 min while being gently shaken (60 rpm). After it had been hybridized, the chip was washed four times with $0.1 \times$ SSC and then incubated in $1 \times$ blocking reagent at room temperature for $1 \mathrm{~h}$. The digoxigenin that had hybridized to the DNA probes on the chip was then recognized by incubating the chip with 0.375 units of anti-digoxigenin-alkaline phosphatase Fab fragments (Roche) for $1 \mathrm{~h}$. After it had been incubated, the chip was washed 3 times with MAB washing buffer (MAB: $0.1 \mathrm{M}$ maleic acid, $0.15 \mathrm{M} \mathrm{NaCl}, 0.1 \%$ Tween 20 [pH 7.5]) for 15 min each. To detect digoxigenin signals, the chip was first soaked in a detection buffer $(0.1 \mathrm{M}$ Tris-HCl, 0.1 $\mathrm{M} \mathrm{NaCl}$ [pH 9.5]) for $5 \mathrm{~min}$ and then incubated with two alkaline phosphatase substrates: nitro blue tetrazolium chloride (NBT, $0.375 \mathrm{mg} / \mathrm{mL}$ ) and 5-bromo-4-chloro-3indolyl phosphate (BCIP, $0.188 \mathrm{mg} / \mathrm{mL}$ ) at $37^{\circ} \mathrm{C}$ for 20 min in the dark. Finally, the chip was washed 3 times with $\mathrm{ddH}_{2} \mathrm{O}$ and air-dried. Chip images were scanned using an Epson Perfection 1250 scanner [32]. 


\section{Results}

Using DNA sequencing analysis, we first detected pre-S deletion mutations in the sera of HBV carriers and patients with HBV-related HCC. The pre-S mutation rate was relatively low $(7 \%)$ in the sera of patients with high HBV titers, which indicates the acute phase of HBV infection (Table 2). The pre-S deletion rate gradually increased during periods of persistent HBV infection: the rate was $37 \%$ in HBV carriers with low serum HBV titers, which indicated the chronic phase of HBV infection. In HCC patients with $\mathrm{HBV}$ infection, the pre-S deletion rate was as high as $60 \%$, which suggested that pre-S mutants emerge during long-term persistence of the HBV genome in carriers, and that they facilitate the development of HCC.

To efficiently detect pre-S deletion mutations, we developed a Pre-S Gene Chip on which contained 42 DNA probes that targeted the pre-S region of the LHBS gene (Fig. 2). To test the efficacy of the chip, we first used isolated plasmids containing wild-type HBV, pre- $S_{1}$ mutant with nt 3044 to 3103 of the LHBS gene deleted, and pre$\mathrm{S}_{2}$ mutant with nt 3 to 57 deleted [28]. These wild-type and pre-S mutant LHBS genes were initially isolated from genotype B HBV carriers in Taiwan [11,12]. The wild-type clone hybridized to all the DNA probes on the chip (Fig. 4). The pre- $S_{1}$ and $-S_{2}$ mutants, however, showed signals missing in probes 6 to 7 , which spanned nt 3044 to 3103 in the pre- $S_{1}$ region, and probes 12 to 13 , which spanned nt 3 to 62 in the pre- $S_{2}$ region, respectively. These results showed that the Pre-S Gene Chip correctly detected the pre-S deletions in the LHBS gene.

We then did a blind test on 20 cases to compare the pre-S typing results yielded by the Pre-S Gene Chip with those provided by classic DNA sequencing. Overall, the Pre-S Gene Chip yielded consistent pre-S deletion detection results with DNA sequencing (Table 3). Because the Pre-S Gene Chip used DNA hybridization signals to detect DNA deletions, the ranges spanning the deleted regions might have shifted a few nucleotides from the DNA sequencing results; however, that appeared not to have affected its identifying pre-S deletions in samples. In summary, DNA sequencing and Pre-S Gene Chip analyses were used to identify 21 and 19 pre-S deletion clones, respectively. The detection rates for pre-S deletions in these HBV carriers were 70\% (14/20) for DNA sequencing and 65\% (13/20) for the Pre-S Gene Chip. These data indicated that the Pre$S$ Gene Chip offered a sensitive assay compatible with DNA sequencing. We also found that 9 of the 14 pre-S mutant-positive cases had multiple pre-S products and that most (8/9) simultaneously contained wild-type as well as pre-S mutants. In addition, 4 cases had multiple mutation clones. This finding showed that wild-type and multiple pre-S mutant LHBS clones often co-existed in one individual.

\section{Discussion}

In this study, we developed an oligonucleotide array system to detect deletions in the pre-S regions of the HBV LHBS gene in chronic carriers with detectable HBV DNA, the group of carriers at a high risk of HCC [10]. We found that multiple mutation clones often co-exist in a carrier, making genotyping tedious and time-consuming. Cloning individual PCR products is usually necessary to differentially genotype the different pre-S deletion products. We found that doing colony PCR of the individual gene clones, and then directly applying the PCR products to the Pre-S Gene Chip for hybridization and detection, was more time- and cost-effective than traditional DNA sequencing analysis. The Pre-S Gene Chip is made of a $0.7-\mathrm{cm}^{2}$ nylon membrane and costs substantially less than DNA sequencing analysis, especially for clinical institutions without internal access to a DNA sequencing service. The DNA chip system also simultaneously detects multiple pre-S clones, which makes it convenient for large-scale pre-S mutation screenings in chronic HBV carriers. Using the Pre-S Gene Chip and DNA sequencing in blind tests of 20 cases showed that both methods had close detection rates of pre-S deletions. Therefore, we conclude that the Pre-S Gene Chip delivered comparable results to direct

Table 2: Pre-S mutations in patients with different serum HBV DNA titers

\begin{tabular}{|c|c|c|c|c|c|}
\hline Status & Serum HBV DNA Titer* & Cases (n) & HBV Clones\# (n) & Clones with Pre-S Deletions (n) & Prevalence \\
\hline \multirow[t]{3}{*}{ Hepatitis } & High & 53 & 57 & 4 & $7.0 \%$ \\
\hline & Intermediate & 62 & 72 & 10 & $13.9 \%$ \\
\hline & Low & 43 & 54 & 20 & $37.0 \%$ \\
\hline $\mathrm{HCC}$ & - & 43 & 73 & 44 & $60.3 \%$ \\
\hline
\end{tabular}

HCC, hepatocellular carcinoma.

*High titer: $\mathrm{HBV}$ genome $\geq 10^{8}$ copies/mL serum; intermediate titer: $\mathrm{HBV}$ genome $\geq 10^{6}$ and $<10^{8} \mathrm{copies} / \mathrm{mL}$ serum; low titer: $\mathrm{HBV}$ genome $<10^{6}$ copies/mL serum.

\#The different pre-S HBS PCR products in one case were individually cloned and sequenced. 

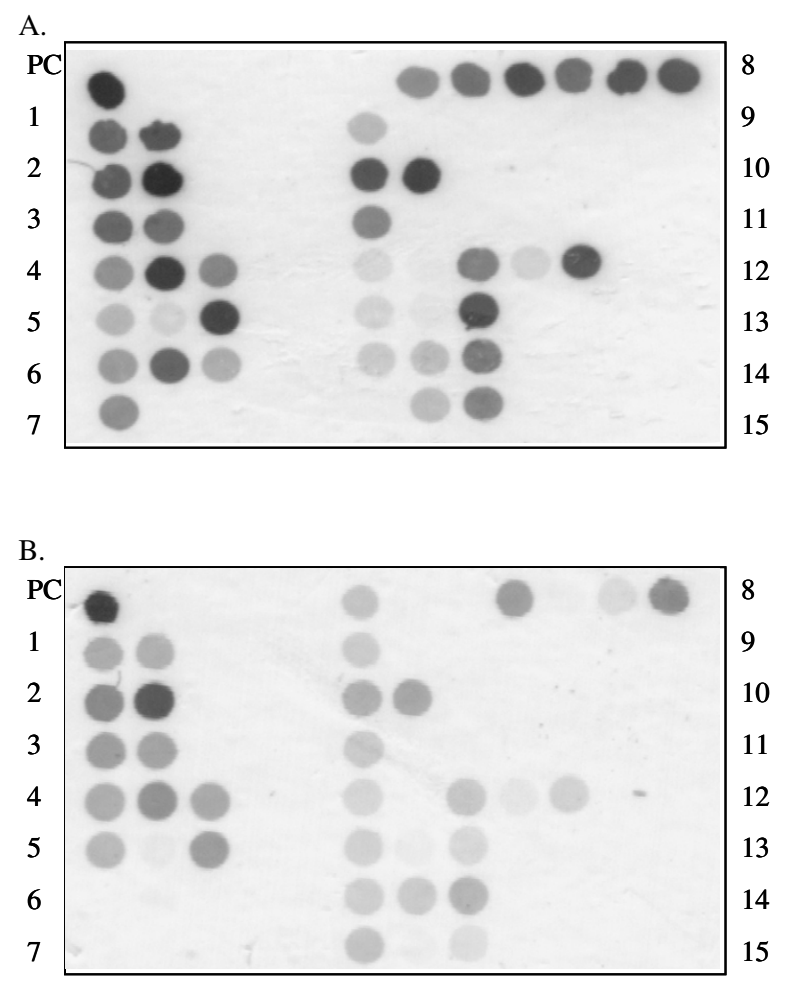

C.

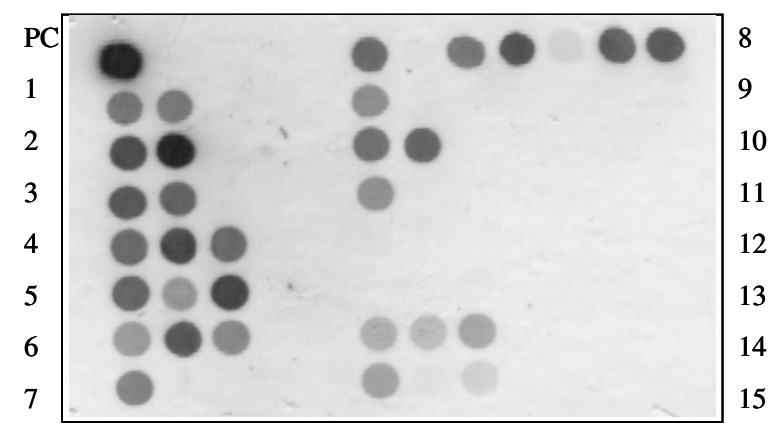

Figure 4

Results of the Pre-S Gene Chip analysis. A: The wildtype LHBS gene. B: The pre-S, mutant LHBS, with nt $3044-$ 3103 of the HBV genome deleted. The signals on probes 6 (nt 3045-307I) and 7 (nt 3074-3 I03) are negative. C: The pre- $\mathrm{S}_{2}$ mutant LHBS, with nt 3-57 of the HBV genome deleted. The signals on probes I 2 (nt 3-32) and I 3 (nt 33-62) are negative.

DNA sequencing and is a good screening method for pre$S$ deletions. A minor disadvantage of the Pre-S Gene Chip system is that it does not appear to be sensitive enough to detect deletions less than $10 \mathrm{nt}$ long: in one blind-tested case, the chip did not identify a 10-nt deletion clone. Nevertheless, considering cost and convenience, the Pre-S
Gene Chip is potentially good for large-scale screening of pre-S deletions; perhaps it can be improved.

In this study, we found that pre-S deletion rates were significantly higher in the late phase of chronic HBV infection, which displays lower HBV titers, than in the acute infection phase, which displays high viral titers. In the $\mathrm{HBV}$-induced HCC stage, the pre-S deletion rate was as high as $60 \%$. These findings suggested that pre-S deletions probably occur during long-term persistent HBV infection and eventually become predominant in HBV carriers. Therefore, we hypothesize that pre-S mutants are important in liver carcinogenesis. Our earlier studies [27,28] found that pre-S mutant LHBS accumulated in ER, where it caused ER and oxidative stress $[27,28]$. It also strongly induced DNA damage and mutations, which destabilized the genome [28]. We found that the pre- $S_{2}$ mutant LHBS induces cyclin A overexpression, cell cycle progression, and cell proliferation, all essential factors for carcinogenesis $[29,30]$. These earlier findings showed that pre-S mutant LHBS, especially the pre- $S_{2}$ type, is involved in carcinogenesis. Identifying the pre-S deletion mutations in chronic HBV carriers is therefore important when screening for persons at high risk for HCC.

In addition to pre-S deletions, a number of HBV markers, such as $\mathrm{HBV}$ viral titers and $\mathrm{HBeAg}$, are also believed to be associated with the risk of HCC in chronic HBV carriers $[9,10]$. HBV replication causes liver injury and inflammation, which releases cytokines and facilitates the development of fibrosis and liver cell proliferation [7,8]. In addition, the HBV protein HBX crosstalks with various host factors and behaves as a viral oncoprotein [33,34]. It transactivates a number of cellular promoters, acting on cis-acting regulatory elements [35]. It also regulates proteasome function and, thus, controls the degradation of cellular and viral proteins [36]. We hypothesize that pre-S mutant LHBS strengthens the detrimental effects of HBX protein by increasing cell proliferation and genomic instability, thereby facilitating hepatocellular carcinogenesis.

\section{Conclusion}

We developed the Pre-S Gene Chip system to screen for pre-S deletions in the LHBS gene. The detection sensitivity of the Pre-S Gene Chip for pre-S mutations is close to that of direct DNA sequencing analysis, but it is much more time- and cost-effective. We believe that the Pre-S Gene Chip is feasible for the large-scale screening of pre-S mutations in chronic HBV carriers. Combining the detection of pre-S mutations with other HBV factors, such as HBV viral titers and HBeAg, should offer a reliable predictive method for HCC risk in chronic HBV carriers. 
Table 3: Summary of the pre-S genotyping results by DNA sequencing and Pre-S Gene Chip analysis in 20 HBV carriers.

\begin{tabular}{|c|c|c|}
\hline Case & DNA Sequencing Result & Pre-S Gene Chip Result \\
\hline I & wild-type & wild-type \\
\hline \multirow[t]{2}{*}{2} & I. wild-type & I. wild-type \\
\hline & 2. del nt 2894 to 3100 & 2. del nt 2894 to 3013 and nt 3074 to 3103 \\
\hline 3 & wild-type & wild-type \\
\hline 4 & wild-type & wild-type \\
\hline \multirow[t]{2}{*}{5} & I. wild-type & I. wild-type \\
\hline & 2. del nt 3040 to 3111 & 2. del nt 3044 to 3103 \\
\hline 6 & wild-type & wild-type \\
\hline 7 & del nt 3218 to 8 & wild-type \\
\hline \multirow[t]{4}{*}{8} & I. wild-type & I. wild-type \\
\hline & 2. del nt 3084 to 3188 & 2. del nt 3074 to 3103 and nt 3134 to 3193 \\
\hline & 3. del nt 3148 to 29 & 3. del nt 3134 to 32 \\
\hline & 4. del nt 3138 to 59 & 4. del nt 3134 to 62 \\
\hline \multirow[t]{2}{*}{9} & I. wild-type & I. wild-type \\
\hline & 2. del nt 3202 to 36 & 2. del nt 3194 to 32 \\
\hline 10 & del nt. 2913 to 3118 and nt 3217 to 9 & del nt 2924 to 2983 and nt 3014 to 3103 \\
\hline 11 & Wild-type & wild-type \\
\hline 12 & wild-type & wild-type \\
\hline \multirow[t]{5}{*}{13} & I. wild-type & I. wild-type \\
\hline & 2. del nt 3022 to 3205 & 2. del nt 3014 to 3103 and $n t 3134$ to 2 \\
\hline & 3. del nt 3132 to 37 & 3. del nt 3134 to 32 \\
\hline & 4. del nt 3057 to 3198 & 4. del nt 3074 to 3103 and nt 3134 to 3193 \\
\hline & 5. del nt 3132 to 3182 & 5. del nt 3134 to 3193 \\
\hline 14 & del nt 2854 to 287 I & del nt 2854 to 2878 \\
\hline \multirow[t]{2}{*}{15} & I. del nt 3205 to 3213 & I. wild-type \\
\hline & 2. del nt 34 to 54 & 2. del nt 33 to 62 \\
\hline \multirow[t]{3}{*}{16} & I. wild-type & I. wild-type \\
\hline & 2. del nt $304 \mid$ to 3126 & 2. del nt 3044 to 3103 \\
\hline & 3. del nt 25 to 56 & 3. del nt 33 to 62 \\
\hline \multirow[t]{2}{*}{17} & I. wild-type & I. wild-type \\
\hline & 2. del nt 2984 to 3221 & 2. del nt 2984 to 3013 , nt 3044 to 3103 , and nt 3134 to 2 \\
\hline \multirow[t]{2}{*}{18} & I. wild-type & I. wild-type \\
\hline & 2. del nt 3 to 56 & 2. del nt 3 to 62 \\
\hline 19 & del nt 3040 to 3111 & del nt. 3044 to 3103 \\
\hline 20 & del nt 2948 to 3097 and nt 3112 to 2 & del nt 2954 to 3013 , nt 3044 to 3103 , and nt 3194 to 2 \\
\hline Pre-S mutant Clones (n) & 21 & 19 \\
\hline Cases with Pre-S Mutations (n) (\%) & $14(70 \%)$ & $13(65 \%)$ \\
\hline
\end{tabular}

nt, nucleotide

\section{Competing interests}

A U.S. Provisional Patent (Title: Oligonucleotides and use thereof for determining deletion in HBV pre-S region. Application No. 61077522, 2008) has been filed for the Pre-S Gene Chip (Fan-Ching Shen, Ih-Jen Su and Wenya Huang). All of the other authors declare that they have no competing interests.

\section{Authors' contributions}

FS carried out the pre-S chip preparation and the majority of molecular studies. IS conceived of the pre-S study project. HW supplied the PCR primer sequences and offered discussion for this study. YH participated in the PCR experiments. WY supplied the patient specimens for pre-S genotyping studies (Table 2). KY supplied control samples for probe design for the pre-S chip. TC offered advice and technical help for probe design for the pre-S chip. HH and HT participated in the evaluation of efficiency of the pre-S chip detection. WH designed the experiments and wrote the manuscript. All authors read and approved the final manuscript.

\section{Acknowledgements}

Supported by grants NHRI-EX95-9520BI (to W. Huang) from the National Health Research Institutes, and CDC-DOH93-DC-I I 28 (to W. Huang)

from the Center for Disease Control, Taiwan.

\section{References}

I. Bréchot C, Gozuacik D, Murakami Y, Paterlini-Bréchot P: Molecular bases for the development of hepatitis B virus (HBV)-related hepatocellular carcinoma (HCC). Sem Cancer Biol 2000, I0:2II-23I.

2. Arbuthnot $P$, Kew $M$ : Hepatitis $B$ virus and hepatocellular carcinoma. Int J Exp Pathol 200I, 82:77-I00. 
3. Parkin DM, Pisani P, Ferlay J: Estimates of the worldwide incidence of the 18 major cancers in 1985. Int J Cancer 1993, 54:1-13.

4. Parkin DM, Whelan SL, Ferlay J, Storm H: Cancer Incidence in Five Continents. In IARC Cancer Base No. 7 WHO Press; 2005.

5. Bosch FX: Global epidemiology of hepatocellular carcinoma. In Liver Cancer Edited by: Okuda K, Tabor E. Churchill Livingstone, New York; 1997:13-28.

6. Beasley J, Hwang LY, Lin CC, Chien CS: Hepatocellular carcinoma and HBV. A prospective study of 22,707 men in Taiwan. Lancet I98I, 2:II290-III33.

7. Levy JA, Owens RA, Fraenkel-Conrat H: Virology. Prentice-Hall, Englewood Cliffs; 1994.

8. Feitelson M: Molecular components of hepatitis B virus. Nijhoff Publications, Boston; 1985.

9. Yang HI, Lu SN, Liaw YF, You SL, Sun CA, Wang LY, Hsiao CK, Chen PJ, Chen DS, Chen CJ: Taiwan Community-Based Cancer Screening Project Group: Hepatitis B e antigen and the risk of hepatocellular carcinoma. N Engl J Med 2002, 347:168-174.

10. Yu MW, Yeh SH, Chen PJ, Liaw YF, Lin CL, Liu CJ, Shih WL, Kao JH, Chen DS, Chen CJ: Hepatitis B virus genotype and DNA level and hepatocellular carcinoma: a prospective study in men. J Natl Cancer Inst 2005, 97:265-272.

II. Fan YF, Lu CC, Chang YC, Chang TT, Lin PW, Lei HY, Su IJ: Identification of a pre- $\mathrm{S}_{2}$ mutant in hepatocytes expressing a novel marginal pattern of surface antigen in advanced disease of chronic hepatitis B virus infection. J Gastro Hepat 2000, 15:519-528.

12. Fan TF, Lu CC, Chen WC, Yao WJ, Wang HC, Chang TT, Lei HY, Shiau AL, Su IJ: Prevalence and significance of hepatitis B virus (HBV) pre-S mutants in serum and liver at different replicative stages of chronic HBS infection. Hepatology 200I, 33:277-286.

13. Bréchot C, Hadchouel M, Scotto J, Fonck M, Potet F, Vyas GN, Tiollais P: State of hepatitis B virus DNA in hepatocytes of patients with hepatitis $B$ surface antigen-positive and negative liver disease. Proc Natl Acad Sci USA 198I, 78:3906-3910.

14. Shafritz DA, Kew MC: Integration of hepatitis B virus DNA into the genome of liver cells in chronic liver disease and hepatocellular carcinoma. N EnglJ Med 198I, 305:1067-1073.

15. Takada S, Gotoh Y, Hayashi S, Yoshida M, Koike K: Structural rearrangement of integrated hepatitis $B$ virus DNA as well as cellular flanking DNA is present in chronically infected hepatic tissues. J Virol 1990, 64:822-828.

16. Hsu T, Moroy T, Etiemble J, Louise A, Trepo C, Tiollais P, Buendia MA: Activation of c-myc by woodchuck hepatitis virus insertion in hepatocellular carcinoma. Cell 1988, 55:627-635.

17. Hadziyannis S, Gerber MA, Vissoulis C, Popper H: Cytoplasmic hepatitis B antigen in "ground-glass" hepatocytes of carriers. Arch Pathol 1973, 96:327-330.

18. Huy TT, Ushijima H, Win KM, Luengrojanakul P, Shrestha PK, Zhong $\mathrm{ZH}$, Smirnov AV, Taltavull TC, Sata T, Abe K: High prevalence of hepatitis B virus pre-s mutant in countries where it is endemic and its relationship with genotype and chronicity. J Clin Microbiol 2003, 41:5449-5455.

19. Santantonio T, Jung MC, Schneider R, Fernholz D, Milella M, Monno L, Pastore G, Pape GR, Will H: Hepatitis B virus genomes that cannot synthesize pre- $S_{2}$ proteins occur frequently and as dominant virus populations in chronic carriers in Italy. Virology 1992, I 88:948-952.

20. Chen BF, Liu CJ, Jow GM, Chen PJ, Kao JH, Chen DS: High prevalence and mapping of pre-S deletion in hepatitis $B$ virus carriers with progressive liver diseases. Gastroenterology 2006, 130:1153-1168.

21. Chen CH, Hung CH, Lee CM, Hu TH, Wang JH, Wang JC, Lu SN, Changchien CS: Pre-S deletion and complex mutations of hepatitis $B$ virus related to advanced liver disease in $\mathrm{HBeAg-neg-}$ ative patients. Gastroenterology 2007, I33:| 466-| 474.

22. Chen $\mathrm{CH}$, Changchien CS, Lee CM, Hung $\mathrm{CH}$, Hu TH, Wang JH, Wang JC, Lu SN: Combined mutations in pre-S/surface and core promoter/precore regions of hepatitis B virus increase the risk of hepatocellular carcinoma: a case-control study. J Infect Dis 2008, 198: | 634-1642.

23. Fang ZL, Sabin CA, Dong BQ, Wei SC, Chen QY, Fang KX, Yang JY, Huang J, Wang $X Y$, Harrison T]: Hepatitis B virus pre-S deletion mutations are a risk factor for hepatocellular carcinoma: a matched nested case-control study. I Gen Virol 2008, 89:2882-2890.

24. Suwannakarn K, Tangkijvanich $P$, Thawornsuk N, Theamboonlers $A$, Tharmaphornpilas P, Yoocharoen P, Chongsrisawat V, Poovorawan $Y$ : Molecular epidemiological study of hepatitis B virus in Thailand based on the analysis of pre-S andS genes. Hepatol Res 2008, 38:244-25I.

25. Kajiya $Y$, Hamasaki K, Nakata K, Nakagawa $Y$, Miyazoe S, Takeda $Y$, Ohkubo K, Ichikawa T, Nakao K, Kato Y, Eguchi K: Full-length sequence and functional analysis of hepatitis $B$ virus genome in a virus carrier: a case report suggesting the impact of pre$\mathbf{S}$ and core promoter mutations on the progression of the disease. J Viral Hepat 2002, 9:149-156.

26. Preikschat P, Günther S, Reinhold S, Will H, Budde K, Neumayer HH, Krüger DH, Meisel H: Complex HBV populations with mutations in core promoter, $\mathrm{C}$ gene, and pre-S region are associated with development of cirrhosis in long-term renal transplant recipients. Hepatology 2002, 35:466-477.

27. Wang HC, Wu HC, Chen CF, Lei HY, Su IJ: Different types of ground glass hepatocytes in chronic hepatitis $B$ virus infection contain specific pre-S mutants that may induce endoplasmic reticulum stress. Am J Path 2003, 163:244I-2449.

28. Hsieh YH, Su IJ, Wang HC, Chang WW, Lei HY, Lai MD, Chang WT, Huang W: The pre-S mutant surface antigens in chronic hepatitis $B$ virus infection induce oxidative stress and DNA damage. Carcinogenesis 2004, 25:2023-2032.

29. Wang HC, Chang WT, Chang WW, Wu HC, Huang W, Lei HY, Lai MD, Fausto N, Su IJ: Upregulation of cyclin A and nodular proliferation of hepatocytes induced by a pre- $S_{2}$ deletion mutant in chronic HBV infection. Hepatology 2005, 41:761-770.

30. Hsieh YH, Su IJ, Wang HC, Tsai JH, Chang WW, Lai MD, Lei HY, Huang W: Hepatitis $B$ virus pre- $S_{2}$ mutant surface antigen induces degradation of cyclin-dependent kinase inhibitor p27 Kipl through c-Jun activation domain-binding protein I. Mol Cancer Res 2007, 5: 1063-1072.

31. Schlicht $H J$, Schaller $H$ : Analysis of hepatitis B virus gene functions in tissue culture and in vivo. Curr Top Microbiol Immunol 1989, 144:253-263.

32. Chang HC, Tsai JH, Guo YL, Tsai P, Li C, Huang W: Differential UVC-induced gadd45 gene expression in xeroderma pigmenstosum cells. Biochem Biophy Res Comm 2003, 305: I I09-IIII5.

33. Natoli G, Avantaggiati ML, Chirllo P, Costanzo A, Artini M, Balsano C, Levrero M: Induction of the DNA-binding activity of c-jun/ c-fos heterodimers by the hepatitis B virus transactivator pX. Mol Cell Biol 1994, 14:989-998.

34. Natoli G, Avantaggiati ML, Chirillo P, Puri PL, lanni A, Balsano C, Levrero M: Ras- and Raf-dependent activation of c-jun transcriptional activity by the hepatitis $B$ virus transactivator $\mathbf{p X}$. Oncogene 1994, 9:2837-2843.

35. Benn J, Su F, Doria M, Schneider RJ: Hepatitis B virus HBx protein induces transcription factor AP-I by activation of extracellular signal-related and c-Jun $\mathrm{N}$-terminal mitogen-activated protein kinases. J Virol 1996, 70:4978-4985.

36. Becker SA, Lee TH, Butel JS, Slagle BL: Hepatitis B virus $\mathbf{X}$ protein interferes with cellular DNA repair. J Virol 1998, 72:266-272.

Publish with BioMed Central and every scientist can read your work free of charge

"BioMed Central will be the most significant development for disseminating the results of biomedical research in our lifetime. "

Sir Paul Nurse, Cancer Research UK

Your research papers will be:

- available free of charge to the entire biomedical community

- peer reviewed and published immediately upon acceptance

- cited in PubMed and archived on PubMed Central

- yours - you keep the copyright 